\title{
STUDIES OF PARASITIC WASPS (HYMENOPTERA: BRACONIDAE) IN association With Mountain Pine BeEtle OUTBReaK
}

\author{
LARRY HAIMOWITZ $\downarrow$ SCOTT SHAW $\uparrow$ DEPARTMENT OF ECOSYSTEM SCIENCES \\ UNIVERSITY OF WYOMING $\uparrow$ LARAMIE
}

\section{$\downarrow$ AbSTRACT}

A survey of parasitoid wasps (Hymenoptera: Braconidae) in Grand Teton National Park reveals undiscovered (but not unexpected) diversity, as well as changes in diversity associated with the bark beetle epidemic and the unusually warm, dry year. Our 2012 survey found nearly the same number of Braconidae subfamilies (18 vs 19) as a 2002 survey (Shaw 2002); a remarkable amount of diversity given that the 2002 survey was based upon five times as many specimens. Eleven species found in this study are new distribution records for the Greater Yellowstone Ecosystem (GYE), which points to much undiscovered local diversity. Differences from previous studies are possibly due to the unusual warmth and dryness of spring 2012, along with some influence from beetle kill. We provide a list of parasitoids and predators associated with mountain pine beetle (Dendroctonus ponderosae Hopkins) in the Greater Yellowstone Ecosystem (GYE), a stepping stone for further research to determine the role of natural enemies in bark beetle outbreak dynamics in the GYE.

\section{$\downarrow \quad$ INTRODUCTION}

Our study was focused on three questions: 1) Is there significant diversity of braconid parasitoids in GYE undiscovered by previous studies? 2) How have bark beetle infestations affected the make-up of the parasitoid community? 3) Which natural enemies of mountain pine beetle (Dendroctonus ponderosae Hopkins) are present in the lodgepole pine (Pinus contorta) forests of GYE?
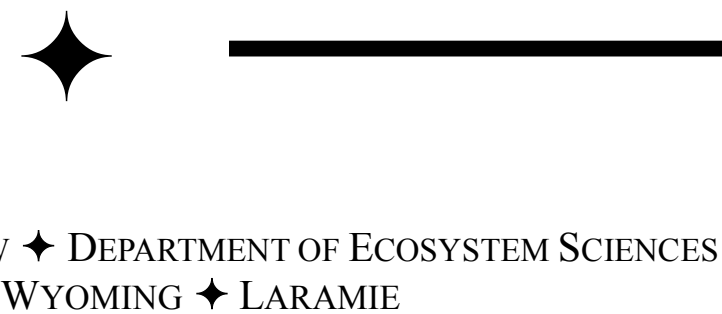

The first goal of our study was to conduct general sampling of parasitoid wasps as follow-up to two previous studies of parasitoid diversity in the GYE (Lockwood et al. 1996; Shaw 2002). These previous studies resulted in the discovery of 100 new distribution records for braconid wasps, and at least ten undescribed species. Based on these results, along with the paucity of hymenopteran research in this region, we expected to find a high proportion of new distribution records, thus adding to our knowledge of insect diversity in this area of the Rocky Mountains. Finding a high proportion of unrecorded species would indicate a much greater diversity than is already known and would point to the need for further studies.

The second goal was to provide an initial assessment of how parasitoid faunas are changing over time in response to the bark beetle epidemic. The current bark beetle epidemic in the GYE is part of a large-scale historical event that may affect biodiversity well into the foreseeable future. In the current, early post-epidemic period, increases in insects that utilize early stages of decaying wood, large numbers of bark beetles, and an associated decline in insects utilizing living pine trees are expected, along with a parasitoid insect fauna that reflects these changes (Stephen and Dahlsten 1976). Over the years, this stage may be followed by a succession of changing resources and conditions extending through time until reaching a new equilibrium, one that may or may not resemble the forest before the beetle epidemic, and which can present new challenges for forest management. Research in both biological and sociological parameters is essential to understand this succession, and to successfully meet the resulting new management challenges (Progar et al. 2009). 
The third goal was to survey and inventory parasitoid wasps and other natural enemies associated with the mountain pine beetle. Comparatively little is known about bark beetle/natural enemy associations in the GYE, except by inference from studies in other Rocky Mountain habitats. Understanding the role of natural enemies in bark beetle population dynamics in the GYE begins with knowing which natural enemies are present. Our western forests are experiencing historically unprecedented bark beetle epidemics that have been largely ascribed to climate change and other anthropogenic changes (Bentz et al. 2010; Lundquist and Bentz 2009). Experience is validating modeling predictions that mountain pine beetle epidemics will continue to climb elevational and latitudinal gradients (Amman, 1973; Hicke et al. 2006). However, climate change is one of many factors - the lodgepole forest in the Jackson Hole Valley did not appear to have sustained as much beetle kill as some surrounding areas, mostly at higher elevations (personal observation), for reasons that are not clear. It is known that many factors, including natural enemies, play a role in the dynamics of bark beetle epidemics (Raffa et al. 2008), and that better information and models are required to predict the future risk and to make appropriate management decisions (Bentz et al. 2008).

\section{$\uparrow \quad$ METHODS}

Insects were collected in lodgepole forests with two Townes-style Malaise flight-intercept traps at ground level in the same locations on the AMK Ranch as in Shaw's 2002 study. We chose to replicate the 2002 study as closely as we could for reasons of comparison. In addition, we placed canopy Malaise traps in four lodgepole pines, two at the AMK ranch where there was little evidence of beetle activity, and two in an area of much higher beetle activity approximately one quarter mile west of the Potholes parking area along Teton Park Road; both forested areas are at nearly the same elevation, and were visually matched for density and maturity (closed canopy with some openings and open understory). The canopy traps were placed adjacent to tree trunks approximately eight feet off the ground to be in the region of the trunk attacked by mountain pine beetle and high enough to avoid damage from wildlife. A Malaise flight intercept trap is a tent-like structure with a sheer fabric barrier that flying insects bump into, while additional barriers in the trap direct the insects into a collecting jar filled with alcohol (or other killing agent). We chose Malaise traps for our study because many previous studies have demonstrated the utility of this kind of trap for sampling Braconidae in forested areas (Lewis and Whitfield 1999; Mazon and
Bordera 2008; Shaw 2002; Noyes 1989). Although we did not find any reference to using Malaise canopy traps for sampling bark beetle associates, we believed the method would work because of its demonstrated effectiveness for sampling flying insects.

Trapping was conducted from July 23 to Aug 10, 2012 and the traps were serviced weekly (insect samples were removed and collection jars refilled with fresh alcohol). On completion of field work, samples were brought to the University of Wyoming, and insects of interest were sorted from the samples, and then chemically dried and mounted for taxonomic study.

Approximately 200 specimens of family Braconidae were prepared and mounted. This family was chosen for study because their hyperdiversity, wide range of hosts, and indirect connections to an even broader spectrum of organisms through their hosts, makes them good indicators for a range of ecological measures (Anderson and Purvis 2008; Anderson et al. 2010; Barbieri Junior and Dias 2012; Lewis and Whitfield 1999; Ueno 2013); and because Dr. Scott Shaw is a specialist in the taxonomy of that group. Specimens were identified to subfamily and genus using keys provided by Goulet and Huber (1993), Shaw (1995), and Wharton et al. (1997). A lack of recent revisions for a large proportion of the Braconidae taxa makes further identification of many specimens difficult (Shaw 2002) so we relied on sorting to morphospecies and comparison with previously identified specimens, a practice that has been validated (Derraik et al. 2010) and which was used in previous surveys. We took a conservative approach to using morphospecies to identify new distribution records, so our proportion of reported new records is likely low.

Three sources of information were used to determine the presence of bark beetle natural enemies in the GYE: our 2012 survey, a literature search, and study of specimens in the University of Wyoming insect collections. To our knowledge, this is the first time anyone has compiled a list of bark beetle natural enemies in the GYE.

\section{$\downarrow \quad$ RESULTS AND DISCUSSION}

In our current study we identified at least 49 braconid wasp species in 18 subfamilies with eleven of those species being new distribution records for the GYE (see appendix for complete list of subfamilies 
and species). The scope of the current study limits comparisons between this and previous surveys to mostly qualitative analysis. We hope for the opportunity for more quantitative analyses in a future study.

Comparison to Previous Studies: We believe our most striking result to be the finding that $20 \%$ of the Braconidae species that we collected were new distribution records for Grand Teton National Park despite the near duplication of Shaw's 2002 survey (same time period and location) - obviously there is still much braconid diversity to be discovered. Climate change along with the unusual 2012 weather may have contributed to this result by altering the temporal distribution of the insects such that some species that were present previously were not present in this time period, and some which hadn't been present previously were present in 2012 during the collection period.

Also striking was a much lower collection rate for Braconidae than in the 2002 survey. Given that we used more traps, we were expecting more insect samples; instead we collected about $20 \%$ of the previous number of Braconidae specimens. This result was likely mostly weather related. During 2012, March and April temperatures averaged 6.1 degrees and 4.1 degrees higher than the respective 2002 monthly averages, which likely resulted in earlier than normal breaking of winter dormancy (see table 1). Also note that June 2012 was much drier and warmer than June 2002, which likely caused an early end to growth and reproductive cycles for many plants and insects. Almost nothing was blooming at the research station during late July of 2012 and much of the vegetation appeared dried out before the start of sampling. Braconid numbers and diversity are directly related to the diversity and density of host species, which in turn are dependent directly or indirectly on vegetation quality. Another important effect of the weather was the lack of nectar sources, upon which many adult braconids depend (Jervis et al. 1993; Williams and Hendrix 2008).

New Distribution Record: Symphya sp: The known hosts of members of this genus are agromyzid fly larvae in the genus Phytobia, which are tree cambium-boring insects (Wharton 1997).

Subfamily Doryctinae: Doryctines are parasitoids of woodboring beetle larvae (Marsh 1965; Wharton et al. 1997). Among the evidence of changes in the parasitoid community due to beetle kill was the finding of three previously unrecorded doryctines in GTNP during 2012.
New Distribution Records: New records are discussed below by subfamily.

Four of the eleven new distribution records are parasitoids of wood-boring insects. Two other new records of special interest are species in the rare genera Holdawayella and Paradelius.

Subfamily Alysiinae: Alysiines are parasitoids of immature stages of flies, and are one of the most important natural control agents of fly populations.

Table 1. Weather records for time periods preceding 2002 and 2012 insect surveys show that the spring and early summer of 2012 were much warmer and drier than during 2002. (Weather records are from the Burro Hill weather station located approximately +450 feet elevation and 14 miles ESE of the AMK Ranch. This is the nearest weather station with records going back to 2002.) Precipitation is expressed as inches and temperature is in degrees Fahrenheit.

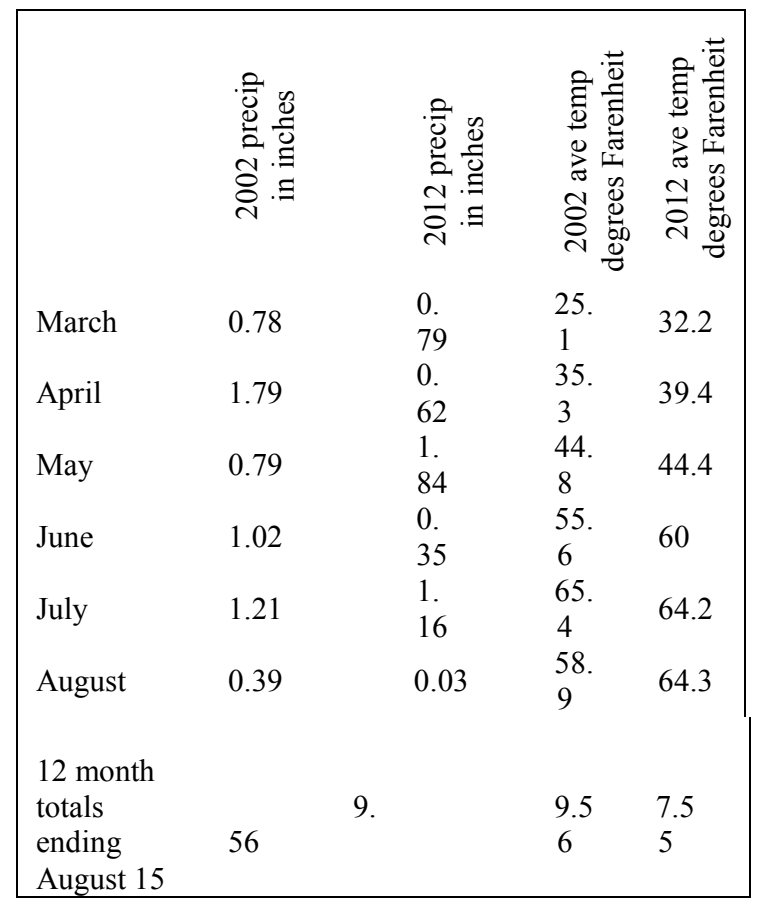

New Distribution Record: Ecphylus species near pacificus Marsh: The known hosts of members of the genus Ecphylus are the larvae of various bark beetles and wood-boring beetles (Marsh 1965; Wharton et al. 1997). A total of six specimens were collected in canopy traps placed in lodgepole pines with active bark beetle infestation. Hosts are not known, but may be mountain pine beetle or a secondary bark beetle. Previous studies did not find any members of genus Ecphylus (Lockwood et al. 
1996; Shaw 2002). If these specimens are E. pacificus, they may represent previously unseen morphological variability in this species. Alternatively, these wasps may prove to be an undescribed species.

New Distribution Records: Herospilus sp. 2 and Heterospilus sp. 3: Genus Heterospilus is associated mostly with wood and bark boring larvae (Marsh 1965) (Wharton et al. 1997). A single specimen of Heterospilus sp. 1 was collected in YNP in $1990-$ a comparison shows this specimen is different from either of the two collected in 2012. These were not keyed to species due to lack of a recent revision of the Nearctic species of this genus.

Subfamily Braconinae: This subfamily contains the genus Coeloides, many of which are important parasitoids of bark beetles, including $C$. rufovariegatus Provancher and $C$. sympitys Mason, which are considered to be among the most important parasitoids of the mountain pine beetle (Amman 1984; Bellows et al. 1998; Mason 1978). Also in this subfamily is the genus Atanycolus whose hosts are almost entirely larvae of wood and bark inhabiting beetles, (Wharton 1997). Given previous records in the GYE and the current bark beetle outbreaks, it was a surprise that neither of these genera were seen in 2012. However, not surprisingly, at least three species of the very speciose genus Bracon were found, including two new distribution records.

New Distribution Records: Bracon sp 1, Bracon sp 2 (Hymenoptera: Braconidae: Braconinae): Members of the subfamily Braconinae are parasitoids on a variety of hosts, mostly lepidopterous and coleopterous larvae in concealed situations. The genus Bracon is very large and diverse; recorded hosts for the genus Bracon are mostly Lepidoptera and Coleoptera, including the larvae of some woodboring beetles (Marsh 1979; Quicke and Sharkey 1989; Muesebeck 1925). Two of the three species of Bracon found in 2012 were not seen previously; this may be due in part to beetle-kill, but is more likely due to the temporal disjunct in developmental cycles caused by the unusual weather patterns last year, and the fact that Bracon is such a large and diverse genus.

Subfamily Euphorinae: Euphorines are unusual in that they attack adult insects - most braconids attack larval stages or pupae (Shaw 2004). Although widespread and diverse, they are often sparsely dispersed throughout the environment and many are rarely collected (Wharton et al. 1997). The 2012 material adds one new distribution record in this subfamily; it should also be noted that, although not a new record, two specimens of a rare species in this subfamily were collected: Myiocephalus boops Wesmael. M. boops is a Holarctic species that is associated with ants, but its biology is unknown (Muesebeck, 1936; Shaw 1985). One of the current specimens was collected in a canopy trap, which may offer a clue to its biology, or it could be a random occurrence - all previous specimens from GYE were collected in ground-based Malaise traps.

New Distribution Record: Holdwayella probably tingiphaga Loan: This is another seldom collected species, and has not been reported from the GYE before. Loan et al. (1971) described the genus Holdawayella, including its biology. The two known species are apparently not distinguishable morphologically, but have a different biology and attack different hosts. H. tingiphaga attacks lace bugs (Tingidae) that live on alder, while the other species attacks tingids on walnut trees. Our sampling location was close to the shore of Jackson Lake, with riparian trees including alder, which supports the identification of $H$. tingiphaga. Additional field work is needed to confirm our identification.

Subfamily Adeliinae: This is a small subfamily of diminutive wasps represented by only two genera and five described species in North America. Though distributed widely, they are rarely collected, probably in part because of their small size. As far as known, they are parasitoids of leaf-mining moths (Wharton et al. 1997; Whitfield 1988).

\section{New Distribution Record: Paradelius sp.}

Subfamily Agathidinae: Agathidinae is a large subfamily with at least 99 species in America north of Mexico (Sharkey 2004). They are recorded as parasitoids of lepidopterous larvae in cases where hosts are known (Wharton et al. 1997).

New Distribution Record: Agathis sp. This is only the second species of Agathis found in the GYE (Shaw 2002).

Subfamily Orgilinae: Members of the subfamily Orgilinae attack Lepidoptera and were one of the most abundant groups in previous surveys of GYE, making up $14 \%$ of the specimens caught in Malaise traps (Shaw 2002). Interestingly, their relative abundance did not change from earlier surveys, though the relative abundances of Cheloninae and Microgastrinae, also parasitoids of Lepidoptera, dropped considerably in 2012.

New Distribution Record: Orgilus sp. near lateralis Cresson: Orgilus lateralis is widespread, 
having been recorded from coast to coast in the US. Muesebeck (1970) believed O. lateralis to possibly be a cluster of separate, related species so this is possibly an undescribed species. This same species has been collected previously in Medicine Bow Routt National Forest in eastern and central Wyoming.

Subfamily Rogadinae: This is a very large subfamily, with some members being quite common. Hosts are caterpillars of Lepidoptera (Wharton et al. 1997).

New Distribution Record: Aleiodes medicinebowensis Marsh and Shaw was originally described from eastern Wyoming (Marsh and Shaw 2001). This record extends its known range to the western part of the state.

Some other notable changes seen in the current survey: The proportion of specimens of the subfamily Microgastrinae was much lower in 2012 (approximately $30 \%$ of specimens) than in 2002 (over $50 \%$ of specimens). This was probably a result of the anomalous spring weather in 2012 which resulted in much lower populations of host plants that support caterpillars - Microgastrinae are the most common parasitoids of caterpillars. One species of Microgastrinae that was quite numerous in previous surveys, Sathon neomexicanus Muesebeck (Williams 1988), was completely absent.

Also notable was the absence of the important bark beetle parasitoids in the genus Ceoloides found in previous surveys - these include Coeloides rufovariegatus Cushman, and Coeloides sympitys Mason. These parasitoids may not have been present during the sampling period in 2012 due to temporal shifts in the wasps' and/or the beetle's life cycles, possibly driven by climate change, and/or by the unusual spring weather of 2012.

Table 2. Test and CI for Two Proportions

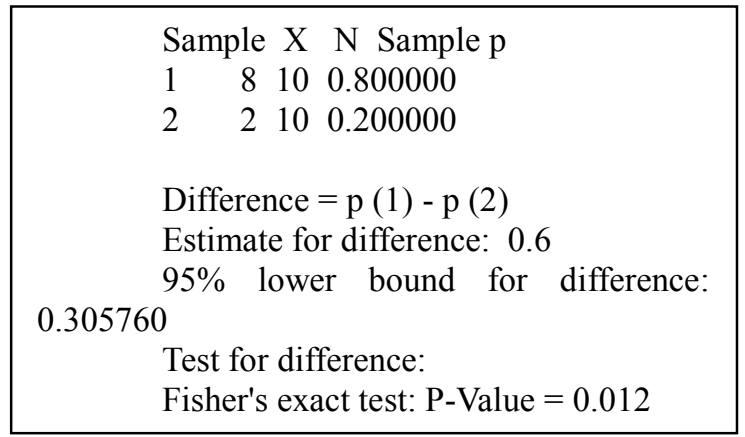

Parasitoid Fauna in Association with Bark Beetle Epidemic: Our study found moderately strong evidence of bark beetle-associated changes in parasitoid communities. Firstly, 35\% of the 2012 new distribution records (four of eleven) are parasitoids of bark or wood boring insects. Secondly, the proportion of wood and bark borer parasitoids was much higher (eight of ten) in the canopy trap sample from beetle infested trees than in the sample (two of ten) from healthy trees. We compared these proportions using a pooled $\mathrm{p}$ and Fisher's exact test to adjust for small sample size (see Table 2).

With this adjustment, our analysis estimates that the likelihood of our result being due to chance is about $1.2 \%$. This is strong evidence for an effect on the parasitoid community in the immediate vicinity of tree trunks, but these samples probably do not account for the majority of the parasitoid diversity, which demonstrably resides closer to the ground among the wider variety of understory plants (in our survey, four canopy traps caught 20 braconids, and two groundbased traps caught 180).

\section{$\uparrow$ CONCLUSIONS \& RECOMMENDATIONS}

Significant diversity of the braconid community remains to be discovered. We strongly believe that a large proportion of the braconid parasitoid diversity in GYE remains to be discovered because our sampling has mostly been limited to a single habitat, lodgepole forest, at one elevation, over short time periods. We recommend a comparative quantitative analysis of biodiversity measures be applied to future surveys; we are quite certain that such an analysis would support the above conclusion. We also recommend continuing inventories of GTNP insects; it is apparent from the rate of discovery of new records that more species records will likely be discovered in the future.

Braconid diversity is affected by beetle kill. We found fairly strong evidence to support this conclusion, though studies that more directly focus on this question are required to better measure this effect. Ground-based Malaise traps placed in beetle killed stands would collect a much more generalized sample and would give a clearer picture of the changes in the parasitoid community. Future surveys should be conducted periodically to monitor forest recovery in areas most hard-hit by beetle kill, as an understanding of the forest response to beetle kill will be needed to guide future management practices.

Natural enemies play a role in bark beetle dynamics. As a first step in understanding the role of natural enemies of bark beetles in the GYE we have created a list of natural enemies of the mountain pine 
beetle in the GYE lodgepole forests. (Table 3) Although this list includes important natural enemies known from other Rocky Mountain forests, there may be local differences that can only be detected by more extended sampling and more applicable sampling methods. Given the very small sample we collected in our canopy traps, we judge that canopy traps are not an effective method of surveying bark beetle associates, so we recommend that future surveys adopt methods proven for the purpose, including emergence traps, and sticky traps (for examples, see Amman1984 and Stephen and Dahlsten 1976). We also recommend studies of the biology of natural enemies, for only by understanding the relationships between bark beetles and their predators and parasitoids can we hope to develop management practices that can enhance the impact of those natural enemies on bark beetle outbreak dynamics. The absence of the common and important bark beetle enemies Coeloides sp. in our current survey also warrants further study, as this finding may indicate changes in the effectiveness of natural enemies due to climate or other changes.

Table 3. Natural Enemies of Mountain Pine Beetle known to occur in GYE

\begin{tabular}{|c|c|c|}
\hline $\begin{array}{l}\text { Species } \\
\text { Coeloides } \\
\text { dendroctoni } \\
\text { Cushman }=C \text {. } \\
\text { rufovariegatus } \\
\text { Provancher }\end{array}$ & $\begin{array}{l}\text { Hymenoptera: } \\
\text { Braconidae }\end{array}$ & $\begin{array}{l}\text { References for } \\
\text { Biology and } \\
\text { Distribution } \\
\text { (Amman 1984; } \\
\text { Bellows et al. 1998; } \\
\text { Mason 1978) }\end{array}$ \\
\hline $\begin{array}{l}\text { Coeloides } \\
\text { sympitys } \\
\text { Mason }\end{array}$ & $\begin{array}{l}\text { Hymenoptera: } \\
\text { Braconidae }\end{array}$ & (Mason 1978) \\
\hline $\begin{array}{l}\text { Rhopalicus } \\
\text { pulchripennis } \\
\text { Crawford }\end{array}$ & $\begin{array}{l}\text { Hymenoptera: } \\
\text { Pteromalidae }\end{array}$ & $\begin{array}{l}\text { (Adams and Six } \\
\text { 2008) }\end{array}$ \\
\hline $\begin{array}{l}\text { Enoclerus } \\
\text { sphegeus } \\
\text { Fabricius } \\
\end{array}$ & $\begin{array}{l}\text { Coleoptera: } \\
\text { Cleridae }\end{array}$ & $\begin{array}{l}\text { (Amman 1984; } \\
\text { Bellows et al. 1998; } \\
\text { Shmid 1970) }\end{array}$ \\
\hline $\begin{array}{l}\text { Thanasimus } \\
\text { undatulus Say }\end{array}$ & $\begin{array}{l}\text { Coleoptera: } \\
\text { Cleridae }\end{array}$ & $\begin{array}{l}\text { (Amman 1984; } \\
\text { Bellows et al. 1998) }\end{array}$ \\
\hline $\begin{array}{l}\text { Temnochila } \\
\text { chloridia } \\
\text { Mannerheim }\end{array}$ & $\begin{array}{l}\text { Coleoptera: } \\
\text { Trogossitidae }\end{array}$ & (Bellows et al. 1998) \\
\hline $\begin{array}{l}\text { Medetera } \\
\text { aldrichii } \\
\text { Wheeler }\end{array}$ & $\begin{array}{l}\text { Diptera: } \\
\text { Dolichopodidae }\end{array}$ & $\begin{array}{l}\text { (Pollet et al. 2004; } \\
\text { Bickel 1985) }\end{array}$ \\
\hline
\end{tabular}

\section{$\downarrow$ ACKNOWLEDGMENTS}

Our thanks go to the following people whose support made this study possible: Celeste Havener, UW-NPS Research Department at UW, for advice and support for preparing the research proposal, and all her help with the logistics and park service contacts after we received our grant; the UW-NPS Research Center Steering Committee for reviewing and accepting our proposal; the National Park and University of Wyoming Small Grant Program for funding our study (grant number 1001489D); Hank Harlow, Director of the UW-NPS Research Station, and the rest of the staff, for maintaining the research station and making it such a great base for our research; Cindy Wood, UW Department of Ecosystems Science and Management, for administering our grant funds; Linda Franklin and Sue Consuelo-Murphy, National Park Service, for reviewing our proposal and issuing our Research Permit (Permit \# GRTE-2012-SCI-0050); and Kelly McClosky, National Park Service, for advice on bark beetle conditions in Grand Teton National Park and her prompt review of our request for an additional study site.

\section{$\downarrow \quad$ Literature Cited}

Adams AS, Six DL. 2008. Detection of host habitat by parasitoids using cues associated with mycangial fungi of the mountain pine beetle, Dendroctonus ponderosea. Canadian Entomologist. 140(1):124-127.

Amman GD. 1973. Population changes of the mountain pine beetle in relation to elevation. Environmental Entomology. 2(4):541- 547.

Amman GD. 1984. Mountain pine beetle (Coleoptera: Scolytidae) mortality in three types of infestations. Environmental Entomology. 13(1):184-191.

Anderson A, Purvis G. 2008. The Value of Hymenoptera as Indicators of Biological Diversity. Prepared by the Agriculture and Food Service Center, University College, Dublin for the Environmental Protection Agency, Johnstown Castle, Co Wexford, Ireland. $72 \mathrm{pp}$.

Anderson A, McCormack S, Helden A, Sheridan H, Kinsella A, Purvis G. 2010. The potential of parasitoid hymenoptera as bioindicators of arthropod diversity in agricultural grasslands. Journal of Applied Ecology. doi: 10.1111/j.1365-2664.2010.01937.x. 9pp.

Barbieri Jr., CA, Dias AMP. 2012. Braconidae (Hymenoptera) fauna in native, degraded and restoration areas of the Vale do Paraiba, Sao 
Paulo State, Brazil. Brazilian Journal of Biology. 72(2):305-310.

Bellows TS, Meisenbacher C, Reardon RC. 1998 Biological Control of Arthropod Forest Pests of the Western United States: A Review and Recommendations. USDA Forest Service: Forest Health Technology Enterprise Team. Morgantown, WV. 126pp.

Bentz BJ, Fettig CJ, Hansen EM, Hayes JL, Hicke J, Kelsey R, Lundquist J, Negron JF, Progar R, Regnieri J, Seybold SJ, Vandygriff HJ. 2008. Climate change and western U.S. bark beetles: rapid threat assessment. Report to the Western Wildlands Environmental Threat Assessment Center, USDA Forest Service, Prineville, Oregon. 79 p.

Bentz BJ, Regnieri J,. Fettig CJ, Hansen EM, Hayes JL, Hicke JA, Kelsey RC, Negron JF, Seybold SJ. 2010. Climate change and bark beetles of the western United States and Canada: direct and indirect effects. Bioscience. 60:602-613.

Bickel DJ. 1985. A revision of the nearctic Medetera (Diptera: Dolochopodidae). USDA Technical Bulletin No 1692. 109 p.

Derraik JGB, Early JW, Closs GP, Dickinson KJM. 2010. Morphospecies and taxonomic species comparison for Hymenoptera. Journal of Insect Science. 10(108):7 pp.

Goulet H, Huber JT, editors. 1993. Hymenoptera of the World: An Identification Guide to Families. Canadian Communication Group Publishing. Ottawa, Canada. 668 pp.

Hicke, JA, Logan JA, Powell J, Olima DS. 2006. Changing temperatures influence suitability for modeled mountain pine beetle (Dendroctonus ponderosae) outbreaks in the western United States. Journal of Geophysical Research: Biogeosciences. Vol 111.G2.doi: 10.1029/2005JG000101.

Jervis MA, Kidd NAC, Fitton NG, Huddleston T, Dawah HA. 1993. Flower-visiting by hymenopteran parasitoids. Journal of Natural History. 27:67-105.

Lewis CN, Whitfield JB. 1999. Braconid wasp (Hymenoptera: Braconidae) diversity in forest plots under different silvicultural methods. Environmental Entomology. 28:986-997.

Loan CC, GH Gerber, DG Reid 1971. Biosystematics of the tingid parasite Holdawayella in Ontario (Hymenoptera: Braconidae: Euphorinae). The Canadian Entomologist. 103:1273-1284.

Lockwood JA, Shaw SR, Struttmann JM. 1996. Biodiversity of wasp species (Insecta, Hymenoptera) in burned and unburned habitats of Yellowstone National Park, Wyoming, USA. Journal of Hymenoptera Research. 5:1-15.

Lundquist JE, Bentz BJ. 2009. Bark beetles in a changing climate. The Western Bark Beetle Research Group: a unique collaboration with Forest Health Protection - proceedings of a symposium at the 2007 Society of American Foresters conference. General Technical Report PNW-GTR-784. Portland OR: US Department of Agriculture, Forest Service, Pacific Northwest Research Station. pp 3949.

Marsh PM. 1965. The nearctic Doryctinae. I. A review of the subfamily with a taxonomic revision of the tribe Hecabolini (Hymenoptera: Braconidae). Annals of the Entomological Society of America. 58(5):668-699.

Marsh PM. 1979. Family Braconidae, In: Krombein KV, Hurd Jr PD, Smith DR, Burks BD, editors. Catalog of Hymenoptera in America North of Mexico. Smithsonian Institution Press, Washington, D.C. pp 144-313.

Marsh PM, Shaw SR. 2001. Revision of North American Aleiodes Wesmael (Part 6): the Gasterator (Jurine) and Unipunctator (Thunberg) species-groups (Hymenoptera: Braconidae: Rogadinae). Proceedings of the Entomological Society of Washington. 103(2)291-307.

Mason WRM. 1978. A synopsis of the nearctic Braconini, with revisions of nearctic species of Coeloides and Myosoma (Hymenoptera: Braconidae). Canadian Entomologist. 110:721-768.

Mazon M, Bordera S. 2008. Effectiveness of two sampling methods used for collecting Ichneumonoidea (Hymenoptera) in the 
Cabaneros National Park (Spain). European Journal of Entomology. 105:879-888.

Muesebeck CFW. 1925. A revision of the parasitic wasps of the genus Microbracon occurring in America north of Mexico. No. 2580, Proceedings U.S. National Museum. 67:8 87pp.

Muesebeck, C.F.W. 1936. The genera of parasitic wasps of the braconid subfamily Euphorinae, with a review of the nearctic species. USDA Miscellaneous Publication No 241. Wahington DC. 38pp.

Muesebeck CFW. 1970. The nearctic species of Orgilus Haliday (Hymenoptera: Braconidae) Smithsonian Contributions to Zoology No 30. Smithsonian Institution Press, Washington DC. 112 pp.

Noyes JS. 1989. A study of five methods of sampling Hymenoptera (Insecta) in a tropical rainforest, with special reference to the parasitica. Journal of Natural History. 23:285-298.

Pollet MAA, Brooks SE, Cumming JM. 2004. Catalog of the Dolichopodidae (Diptera) of America North of Mexico. Bulletin of the American Museum of Natural History. NY, NY. 283:114pp.

Progar RA, Eglitis A, Lundquist JE. 2009. Some ecological, economic, and social consequences of bark beetle infestations. In The Western Bark Beetle Research Group proceedings of a symposium at the 2007 Society of American Foresters conference. General Technical Report PNW-GTR-784. US Department of Agriculture, Forest Service, Pacific Northwest Research Station. Portland OR. pp 39-49.

Quicke DLJ. Sharkey M. 1989. A key to and notes on the genera of Braconinae (Hymenoptera: Braconidae) from America north of Mexico with descriptions of two new genera and three new species. Canadian Entomologist. 121:337-361.

Raffa KF, Aukema BH, Bentz BJ, Carroll AL, Hicke AJ, Turner MG, Romme WH. 2008. Crossscale drivers of natural disturbances prone to anthropogenic amplification: the dynamics of bark beetle eruptions. Bioscience. 58:6 pp 501-517.
Sharkey MJ. 2004. Synopsis of the Agathidinae (Hymenoptera: Braconidae) of America north of Mexico. Proceedings of the Russian Entomological Society. 75(1)134-152.

Shaw SR. 1985. A phylogenetic study of the subfamilies Meteorinae and Euphorinae (Hymenoptera: Braconidae). Entomography. 3:277-370.

Shaw SR. 1995. Braconidae. Subchapter 12.2. In: Hanson PE, Gauld ID, editors. The Hymenoptra of Costa Rica. Oxford University Press, N.Y. pp 431-463.

Shaw SR. 2002. Studies of parasitic wasps (Braconidae) in Grand Teton National Park. University of Wyoming National Park Service Research Center, $26^{\text {th }}$ Annual Report 26. pages 47-56.

Shaw SR. 2004. Essay on the evolution of adultparasitism in the subfamily Euphorinae (Hymenoptera, Braconidae). Proceedings of the Russian Entomological Society. 75(1)8295 .

Stephen FM, DL Dahlsten. 1976. The arrival sequence of the arthropod complex following attack by Dendroctonus brevicomis (Coleoptera: Scolytidae) In ponderosa pine. Canadian Entomologist. 108:283-304.

Ueno T. 2013. Bioindicators of biodiversity and farming practice in rice paddies. International Journal of Chemical, Environmental, and Biological Sciences. 1(1):84-87.

Wharton RA., Marsh PM, Sharkey MJ. 1997. A Manual of the New World Genera of the Family Braconidae (Hymenoptera). The International Society of Hymenopterists. Washington DC.

Whitfield, J.B. 1988. Two new species of Paradelius (Hymenoptera: Braconidae) from North America. Pan-Pacific Entomologist. 64(4):313-319.

Williams DJM. 1988. Classification, phylogeny, and zoogeographic studies of species of Sathon Mason (Hymenoptera, Braconidae), Quaestiones Entomologicae. 24:529-639. 
Williams III L, Hendrix DL. 2008. Comparing different floral resources on the longevity of a parasitic wasp. Agricultural and Forest Entomology. 10:23-28. 
Appendix: List of Subfamilies and Species Found in this Survey

\section{Subfamily Adeliinae}

Paradelius sp. (new distribution record)

\section{Subfamily Agathidinae}

Agathis sp. (new distribution record)

\section{Subfamily Alysiinae}

Aspilota sp.

Chorebus sp.

Dacnusa sp.

Dinotrema sp. 1

Dinotrema sp. 2

Symphya sp. (new distribution record)

\section{Subfamily Aphidiinae}

Aphidius sp.

Binodoxys sp.

Ephedrus sp.

Praon sp.1

Praon sp. 2

\section{Subfamily Blacinae}

Blacus sp.

\section{Subfamily Braconinae}

Bracon sp. 1 (new distribution record)

Bracon sp. 2 (new distribution record)

Bracon sp. 3

\section{Subfamily Cheloninae}

Archiochelonus sp 2

Ascogaster near borealis Shaw

Ascogaster near rufa Muesebeck \& Walkley

Chelonus (Microchelonus) sp. 1

Chelonus (Microchelonus) sp. 2

\section{Subfamily Doryctinae}

Doryctes near fartus (Provancher)

Ecphylus near pacificus Marsh (new distribution record)

Hetrospilus sp. 2 (new distribution record)

Heterospilus sp. 3 (new distribution record)

Ontsira imperator Haliday

\section{Subfamily Euphorinae}

Centistes laevis Cresson

Holdawayella probably tingiphaga Loan (new distribution record)

Myiocephalus boops Wesmael

\section{Subfamily Helconinae}

Wroughtonia probably frigida Cresson

\section{Subfamily Hormiinae}

Hormius sp.

\section{Subfamily Macrocentrinae}

Macrocentrus incompletus Muesbeck

Macrocentrus sp 2

\section{Subfamily Meteorinae}

Meteorus near dimidiatus Cresson

\section{Subfamily Microgastrinae}

Apanteles sp. 1

Apanteles sp. 2

Cotesia sp.

Microplitus sp.

\section{Subfamily Neoneurinae}

Neonuris sp.

\section{Subfamily Opiinae}

Opius sp. 1

Opius sp. 2

Opius sp. 3

\section{Subfamily Orgilinae}

Orgilus near lateralis Cresson (new distribution record)

Orgilis sp.1

Orgilis sp. 2

\section{Subfamily Rogadinae}

Rhysipolis platygaster Spencer

Aleiodes medicinebowensis Marsh and Shaw (new distribution record)

Aleiodes near scrutator Say 